Yatan hastalardan izole edilen Escherichia coli ve Klebsiella spp. suşlarında genişlemiş spektrumlu beta-laktamaz üretimi ve antibiyotik direnç oranları: 2011-2015 verileri

\title{
Extended spectrum beta-lactamase production and antibiotic resistance rates in of Escherichia coli and Klebsiella spp. isolated from hospitalized patients: data of 2011-2015
}

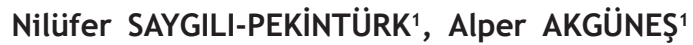

\section{ÖZET}

Amaç: Escherichia coli ve Klebsiella spp. ile olușan ciddi enfeksiyonların tedavisinde üçüncü ve dördüncü kuşak sefalosporinler önemli bir seçenektir. $\mathrm{Bu}$ antibiyotiklere karșı direnç sağlayan genișlemiş spektrumlu beta-laktamazlar (GSBL), tüm dünyada yaygın olarak bulunmaktadır. GSBL olușturan suşlarla hastane enfeksiyonu epidemileri oluşabilmekte ve bu sușlar genellikle çoklu ilaç direncine sahip olduklarından tedavide sorunlar yașanabilmektedir. Etkenlerin ve antibiyotik duyarlılık durumlarının bilinmesi, ampirik tedavinin yönlendirilmesi açısından önemlidir. Bu çalışmada hastanemizde yatan hastalardan izole edilen $E$. coli ve Klebsiella spp. sușlarının dört buçuk yıllık süreçte GSBL olușturma ve antibiyotik direnç durumlarının yıllar içindeki değișiminin saptanması amaçlanmıștır.

Yöntem: Hastanemizde yatan hastalardan, 01 Ocak 2011 - 30 Haziran 2015 tarihleri arasında, mikrobiyoloji laboratuvarına kültür-antibiyogram çalışması yapılmak üzere gönderilen çeșitli örneklerden izole edilen $E$. coli ve Klebsiella spp. sușlarına ait veriler kayıtlardan geriye dönük olarak değerlendirilmiștir. Bakterilerin tanımlanmasında, antibiyotik duyarlılıklarının ve GSBL

\section{ABSTRACT}

Objective: Third and fourth generation sephalosporins are important options for the treatment of infections with Escherichia coli and Klebsiella spp.. Extended spectrum beta-lactamases (ESBL) which provides resistance to these antibiotics, are very common all over the world. These ESBL producing species can make epidemics of hospital infection and the treatment of these infections may be hard thus these species have usually multiple drug resistance. It's important to know the agents and their antibiotic resistance to guide the empirical treatment. In this study it's aimed to detect ESBL production and antibiotic resistance patterns of $E$. coli and Klebsiella spp. species which are isolated from hospitalized patients of our hospital for four and a half years period.

Methods: The data of E. coli and Klebsiella spp. isolated from various samples of hospitalized patients which are sent to our microbiology laboratory for culture and antibiogram tests between 1 January 2011 and 30 June 2015, are analized records retrospectively. Vitek 2 (bioMerioux, France) fully automatized system is used to identify bacteria

${ }^{1}$ Manisa Devlet Hastanesi, Mikrobiyoloji Laboratuvarı, Manisa

İletişim/Corresponding Author: Nilüfer SAYGILI-PEKINTÜRK

Ataşehir Mah. Cehar Dudayev Bulvarı Karya Evleri C Blok Ardıç No: 16 Çiğli İzmir - Türkiye Geliş Tarihi / Received : 16.02 .2016

Tel : +905058114455_E-posta/E-mail : npekinturk@hotmail.com Kabul Tarihi / Accepted : 10.03.2017

DOI ID : 10.5505/TurkHijyen.2017.66933

Saygllı-Pekintürk N, Akgüneș A. Yatan hastalardan izole edilen Escherichia coli ve Klebsiella spp. sușlarında genișlemiș spektrumlu beta-laktamaz üretimi ve antibiyotik direnç oranları: 2011-2015 verileri. Turk Hij Den Biyol Derg, 2017; 74(3): 221-228 
üretiminin belirlenmesinde Vitek 2 (bioMerioux, Fransa) tam otomatize sistem kullanılmıștır.

Bulgular: Çalışmaya toplam 804 E. coli ve 315 Klebsiella spp. sușu dahil edilmiștir. Ortalama $E$. coli'de \%47, Klebsiella spp.'de \%45 GSBL pozitifliği tespit edilmiștir. E. coli'lerde GSBL pozitifliği 2013 yılında 2012'ye göre azalmıș, sonraki yıllarda değișiklik göstermemiștir. GSBL pozitif Klebsiella spp. sușu oranı ilk yıllarda değișmemiș, 2014-2015 yılları arasında ise \%51'den \%22'ye düșmüștür. E. coli'ye en etkili antibiyotikler olan kolistin ve karbapenemlere direnç oranları \%1-\%3 seviyelerindedir. $E$. coli'ye en etkili üçüncü antibiyotik olan amikasine direnç oranı 2011 yılında \%24 iken giderek düșmüș ve 2015 yıllında \%6 olmuștur. Kolistin ve amikasin Klebsiella spp. için E. coli'ye oranla oldukça yüksek direnç oranları göstermelerine rağmen en etkili antibiyotiklerdir. Klebsiella bakterisinin karbapenemlere karșı \%50’ler seviyesine ulașan yüksek direnç oranları dikkat çekicidir.

Sonuç: Hastanemizde yatan hastalardan izole edilen $E$. coli ve Klebsiella spp. için antibiyotik direnci önemli bir sorundur. Çeșitli antibiyotik kombinasyonları ile tedavi edilmeye çalıșılan bu suşlarla oluşan enfeksiyonlar endișe vericidir ve acil müdahale gerektirmektedir.

Anahtar Kelimeler: Escherichia coli, Klebsiella, antibiyotik direnci and to detect antibiotic susceptibility and ESBL production.

Results: Totally 804 E. coli ve 315 Klebsiella spp. strains are included in the study. As an average $47 \%$ E. coli and $45 \%$ Klebsiella spp. strains were detected positivity ESBL. The ESBL positivity of $E$. coli is decreased in 2013 respect to 2012 and no change has been occured following years. The ratio of ESBL positive Klebsiella spp. strains didn't change for first years, but it decreased from 51\% to 22\% between 2014 and 2015 . Resistance ratio to colistin and carbapenems which are the most effective antibiotics to E.coli is about $1-3 \%$. The resistance ratio to amikacine the third most effective antibiotic to $E$. coli was $24 \%$ in 2011 and decreased by years to $6 \%$ at 2015 . Colistin and amikacine are the most effective antibiotics to Klebsiella spp. although they show very high resistance rates compare to $E$. coli. The high resistance ratios of carbapenems to Klebsiella spp. which are reached to $50 \%$ levels attract attention.

Conclusion: In our hospital, antibiotic resistance is an important problem for $E$. coli and Klebsiella spp. isolated from hospitalized patients. Infections by these strains which are tried to be treated by antibiotic combinations, are worrying and must be handled urgently.

Key Words: Escherichia coli, Klebsiella, antibiotic resistance

\section{Giriș}

Gram negatif enterik bakteriler giderek artan direnç sorunu nedeniyle klinik uygulamalarda hekimleri zora sokan güncel etkenlerdir. Bu bakterilerle olușan ciddi enfeksiyonların tedavisinde önemli bir seçenek olan üçüncü ve dördücü kuşak sefalosporinlere karșı direnç sağlayan genişlemiș spektrumlu beta-laktamazlar (GSBL), tüm dünyada yaygın olarak bulunmakta ve en sık hastanede yatmakta olan hastalardan izole edilen Klebsiella pneumoniae ve Escherichia coli sușlarında saptanmaktadır (1).

Genişlemiş spektrumlu beta-laktamazların temel özelliği dar ve geniș spektrumlu sefalosporinleri, penisilinleri ve monobaktamları (aztreonam) hidrolize ederek inaktive etmeleri ve sefamisinler (sefoksitin, sefotetan) ile karbapenemleri inaktive 
etmemeleridir. Oluşan mutasyonlar sonucunda gelișen aminoasit modifikasyonları ile yeni GSBL'ler oluşmaktadır. Bir klinik izolatta aynı anda birden çok GSBL enzimi bulunabilmektedir. GSBL'ler klonal yayılım veya konjugatif plazmid transferi ile diğer mikroorganizmalara direnci aktarabilmektedirler (2). GSBL oluşturan sușlarla hastane enfeksiyonu epidemileri oluşabilmekte ve bu suşlar genellikle çoklu ilaç direncine sahip olduklarından tedavide sorunlar yaşanabilmektedir (3). Etkenlerin ve antibiyotik duyarlıık durumlarının bilinmesi, ampirik tedavinin yönlendirilmesi açısından önemlidir (2).

$\mathrm{Bu}$ çalışmada, hastanemizde yatan hastalardan izole edilen $E$. coli ve Klebsiella spp. suşlarının 01 Ocak 2011 ve 30 Haziran 2015 tarihleri arasında GSBL olușturma ve antibiyotik direnç durumlarının yıllar içerisindeki değișiminin saptanması amaçlanmıștır.

\section{GEREÇ ve YÖNTEM}

Manisa Devlet Hastanesi servislerinde yatan hastalardan, 01 Ocak 2011 ve 30 Haziran 2015 tarihleri arasında, mikrobiyoloji laboratuvarına kültürantibiyogram çalıșması yapılmak üzere gönderilen çeşitli örneklerden izole edilen $E$. coli ve Klebsiella spp. suşlarına ait veriler geriye dönük olarak laboratuvar kayıtlarından elde edilmiştir. Bakterilerin tanımlanmasında, antibiyotik duyarlılıklarının ve GSBL üretiminin belirlenmesinde Vitek 2 (bioMerioux, Fransa) tam otomatize sistem kullanılmıștır. Bakteri tanımlamasında, Vitek 2 GN (kolorimetrik) kartı, antibiyotik duyarlılı testlerinde ve GSBL tespitinde ise ilk iki yıl AST-N091 kartı, Kasım 2012'den itibaren ise AST-N261 kartı kullanılmıștır. Bu kartlarda sefepim (klavulanik asitli ve klavulanik asitsiz), sefotaksim (klavulanik asitli ve klavulanik asitsiz), seftazidim (klavulanik asitli ve klavulanik asitsiz) olmak üzere altı kuyucuktaki antibiyotik konsantrasyonları değerlendirilerek sonuç verilmektedir Otomatize sistem gerektiğinde firma tarafından Klinik Laboratuvar ve Standartları Enstitüsü (Clinical Laboratory Standards Institute, CLSI) kriterlerine göre revize edildiğinden sușların GSBL üretimi o sırada geçerli CLSI kriterlerine göre belirlenmiş, kaydedilmiş ve sonuçlar bu kayıtlardan çıkarılmıştır. Çalıșma verilerinin değerlendirildiği süreçte tanımlama ve antibiyogram iç kalite kontrol çalıșmaları haftada bir E. coli ATCC 25922 ve S. aureus ATCC 29213 suşları ile yapılmıștır. Dış kalite kontrol çalıșmalarında ise yıllara göre değișmekle birlikte Tıbbi Laboratuvar Değerlendirme (Medical Laboratory Evaluation, MLE) veya Amerikan Patologlar Koleji (College of American Pathologists, (AP) programlarına katılım ile sağlanmıștır. Bir hastadan izole edilen ilk suş çalışmaya dahil edilmiş, tekrarlayan suşlar dikkate alınmamıștır. Orta derecede duyarlııı gösteren suşlar dirençli kabul edilmiștir. Verilerin istatistiksel analizi ki kare testi ile değerlendirilmiş, $p<0,05$ değeri anlamlı olarak kabul edilmiștir.

\section{BULGULAR}

01 Ocak 2011 ve 30 Haziran 2015 tarihleri arasında çalışmaya, toplam 804 E. coli ve 315 Klebsiella spp. sușu dahil edilmiștir. Klebsiella spp. sușlarının 293'ü K. pneumoniae, 21'i K. oxytoca ve biri $K$. ozanea olarak tespit edilmiștir. E. coli’lerin \%23’ü, Klebsiella spp.'lerin \%45'i yoğun bakımlarda yatan hastalardan izole edilmiștir. Dört $E$. coli ve iki Klebsiella spp. suşunda GSBL değerlendirilmemiștir. Toplamda $E$. coli'de \%47, Klebsiella spp.'de \%45 GSBL pozitifliği tespit edilmiștir. GSBL olușturma sayı ve oranları Tablo 1'de verilmiştir.

E. coli'lerde yıllara göre GSBL pozitifliği anlamlı bir değișiklik göstermemiștir $(p=0,21)$. Klebsiella spp. için GSBL pozitifliğinde yıllara göre anlamlı fark bulunmuș, farklıığın 2015 yılından kaynaklandığı ve diğer yıllara göre pozitiflik oranının anlamlı olarak azaldığı tespit edilmiștir $(p=0,004)$.

Tablo 2'de E. coli ve Klebsiella spp. sușlarının GSBL oranları ve antibiyotik direnç durumlarının yıllar içindeki değişimi görülmektedir. 
Tablo 1. E. coli ve Klebsiella spp. için yıllara göre GSBL pozitiflik oranları

\begin{tabular}{|c|c|c|c|c|c|c|}
\hline \multirow{2}{*}{ YIL } & \multicolumn{3}{|c|}{ E. coli } & \multicolumn{3}{|c|}{ Klebsiella spp. } \\
\hline & $\mathrm{n}$ & GSBL $(+)$ & $\%$ & $\mathrm{n}$ & GSBL (+) & $\%$ \\
\hline 2011 & 102 & 51 & 50 & 51 & 29 & 57 \\
\hline 2012 & 196 & 105 & 54 & 66 & 35 & 53 \\
\hline 2013 & 196 & 84 & 43 & 69 & 30 & 43 \\
\hline 2014 & 179 & 79 & 44 & 81 & 41 & 51 \\
\hline 2015 & 127 & 58 & 46 & 46 & 10 & 22 \\
\hline Toplam & 800 & 377 & 47 & 313 & 145 & 45 \\
\hline
\end{tabular}

Tablo 2. E. coli ve Klebsiella spp. sușlarının antibiyotik direnç durumlarının yıllar içindeki değișimi

\begin{tabular}{|c|c|c|c|c|c|c|c|c|c|c|c|c|c|c|}
\hline \multirow[b]{2}{*}{ Antibiyotik } & \multicolumn{7}{|c|}{ E. coli (\%) } & \multicolumn{7}{|c|}{ Klebsiella spp. (\%) } \\
\hline & 2011 & 2012 & 2013 & 2014 & 2015 & $\begin{array}{l}\frac{\pi}{E} \\
\frac{\pi}{\pi} \\
\stackrel{0}{\frac{\pi}{0}}\end{array}$ & 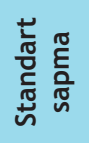 & 2011 & 2012 & 2013 & 2014 & 2015 & $\begin{array}{l}\frac{\pi}{E} \\
\frac{\pi}{\pi} \\
\stackrel{\mathbb{2}}{0}\end{array}$ & 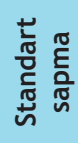 \\
\hline Ampisilin & 78 & 74 & 71 & 73 & 77 & 75 & 2,9 & 100 & 100 & 100 & 100 & 100 & 100 & 0,0 \\
\hline $\begin{array}{l}\text { Amoksisilin- } \\
\text { Klavulonik asit }\end{array}$ & 64 & 45 & 37 & 47 & 45 & 48 & 9,9 & 57 & 49 & 41 & 57 & 66 & 54 & 9,4 \\
\hline Amikasin & 24 & 15 & 7 & 10 & 6 & 12 & 7,4 & 8 & 18 & 7 & 41 & 37 & 22 & 16,0 \\
\hline Ertapenem & 0 & 2 & 1 & 3 & 1 & 1 & 1,1 & 6 & 11 & 6 & 38 & 52 & 23 & 21,1 \\
\hline Gentamisin & 44 & 46 & 28 & 30 & 29 & 35 & 8,8 & 41 & 24 & 20 & 47 & 46 & 36 & 12,7 \\
\hline İmipenem & 0 & 0 & 1 & 3 & 2 & 1 & 1,3 & 2 & 7 & 0 & 38 & 50 & 19 & 23,0 \\
\hline Kolistin & - & 0 & 1 & 1 & 0 & 1 & 0,6 & - & 4 & 0 & 6 & 35 & 11 & 16,0 \\
\hline Levofloksasin & 58 & 52 & - & - & - & 55 & 4,2 & 55 & 43 & - & - & - & 49 & 8,5 \\
\hline Meropenem & 0 & 0 & 1 & 2 & 1 & 1 & 0,8 & 4 & 6 & 1 & 38 & 48 & 19 & 21,9 \\
\hline $\begin{array}{l}\text { Pipersilin- } \\
\text { Tazobaktam }\end{array}$ & 19 & 15 & 11 & 20 & 15 & 16 & 3,6 & 51 & 34 & 20 & 48 & 59 & 42 & 15,4 \\
\hline Sefepim & 15 & 15 & 11 & 16 & 21 & 16 & 3,6 & 37 & 22 & 10 & 47 & 61 & 35 & 20,1 \\
\hline Sefoxitin & 19 & 19 & 15 & 21 & 21 & 19 & 2,4 & 41 & 15 & 10 & 42 & 55 & 33 & 19,2 \\
\hline Seftazidim & 33 & 34 & 24 & 29 & 31 & 30 & 4,0 & 53 & 45 & 31 & 49 & 63 & 48 & 11,7 \\
\hline Seftriakson & 49 & 52 & 42 & 47 & 47 & 47 & 3,6 & 59 & 52 & 47 & 57 & 68 & 57 & 7,9 \\
\hline Sefuroksim & 58 & 57 & 46 & 51 & 48 & 52 & 5,3 & 63 & 55 & 52 & 60 & 70 & 60 & 7,0 \\
\hline Siprofloksasin & - & 50 & 45 & 50 & 54 & 50 & 3,7 & - & 48 & 24 & 52 & 58 & 46 & 14,9 \\
\hline $\begin{array}{l}\text { Trimetoprim- } \\
\text { Sulfametoksazol }\end{array}$ & 59 & 55 & 46 & 45 & 54 & 52 & 6,1 & 59 & 31 & 27 & 56 & 63 & 47 & 16,9 \\
\hline
\end{tabular}

-:Antibiyotik direnç yok. 
E. coli'ye en etkili antibiyotikler olan kolistin ve karbapenemlere direnç oranları \%1-\%3 seviyelerindedir. Amikasine direnç oranı 2011 yılında \%24 iken giderek düșmüş ve 2015 yıllında $\% 6$ olmuştur $(p=0,000)$. Bu nedenle, $E$. coli'ye en etkili antibiyotikler arasında yer almaktadır. Gentamisin direncinde de yıllar içinde azalma ( $p=0,021)$ görülmekle birlikte, ortalama direnç \%35 olarak tespit edilmiștir.

Kolistin ve amikasin, $E$. coli'ye oranla oldukça yüksek direnç oranlarına rağmen Klebsiella spp.'ye en etkili antibiyotikler olarak görülmektedir. Klebsiella spp.'lerde değerlendirilmeye başlandığı 2012 yılında kolistine 23 suşun sadece biri (\%4) dirençli tespit edilmişken, sonraki yıllarda direnç oranı hızla artmış, 2014'de \%6'ya, 2015'de ise \%35'e ulașmıștır. Klebsiella spp.'ler için amikasin direnci de yıllar içinde giderek artmış $(p=0,000)$ ve 2015 yılında \%37 seviyesine ulașmıștır. GSBL olumlu sușların tedavisinde öncelikli tercih edilen karbapenemlerde \%50'ler seviyesine ulaşan yüksek direnç oranları dikkat çekicidir. 2011 yılında 51 suștan sadece biri her üç karbapeneme (imipenem, meropenem ve ertapenem) de dirençli (\%2) olduğu tespit edilmișken, 2014 yilında 81 Klebsiella spp.'den 31'i (\%38), 2015 ylında ise bu üç karbapenemin birlikte değerlendirildiği 40 sușun 18'i (\%45) her üç karbapeneme de dirençli bulunmuștur.

\section{TARTIȘMA}

Enzimatik direnç içinde önemli bir fenotip gösteren GSBL'ler özellikle $E$. coli ve Klebsiella türlerinde yaygın olarak bulunmaktadır. Bu enzim ailesi değişik direnç genotiplerini içeren büyük plazmidler aracılığıyla taşındıkları için çoklu dirence neden olur ve sușlar arasında kolayca yayılabilir. Klinik olarak da önemli enzimlerdir; zira varlıklarının gösterilmesi tedavide kısıtlılığa yol açar. Bu nedenle, hastanelerde GSBL salgılayan bakterilerin sıklığının düzenli olarak izlenmesi ve yayılımının önlenmesi gerekmektedir (5).

Bu zamana kadar çeșitli çalıșmalarla bildirilen GSBL üreten $E$. coli ve Klebsiella türlerinin sıklığı; sușların izole edildikleri örneklere, hastaların ayaktan ya da yatan olmasına, yatan hastaların servislerine, etkenin hastane enfeksiyonu etkeni olup olmamasına ve çalıșmanın yapıldığı yıllara göre farklııı göstermektedir. Ülkemizden bildirilen verilere göre yatan hasta örneklerinden izole edilen $E$. coli ve Klebsiella spp.' de GSBLoranları sirasıyla \%20-44 ve \%24-64 arasında değișmektedir (1, 5-8). Söz konusu sușlar hastane enfeksiyon etkenleri olarak izole edildiğinde oranlar hayli yükselip $E$. coli için \%80'ler, Klebsiella spp. \%90'lar seviyelerine çıkmaktadır (9).

Invazif izolatlara (kan kültürü ve beyin omurilik sıvısı kültürü izolatları) ait verilerin toplandığı Ulusal Antimikrobiyal Direnç Sürveyans Sistemi (UAMDSS) verilerine göre ülkemizde 2013'de GSBL olumluluğu $E$. coli'lerde $\% 44,9$, K. pneumoniae'larda ise $\% 49,9$ olarak belirlenmiștir (10).

SENTRY antimikrobiyal sürveyans programı verilerine göre, pnömoni nedeniyle hastanede yatan hasta örneklerinden izole edilen Klebsiella spp. suşlarında GSBL pozitiflik oranları Amerika Birleșik Devletleri için \%19,5, Avrupa ve Akdeniz bölgesi için ise \%35,1 olarak tespit edilmiștir (11). Avrupa antimikrobiyal direnç sürveyans ağı (EARS-Net) verilerine bakıldığında, invazif $E$. coli izolatlarında 2011 yılında \%9,6 üçüncü kuşak sefalosporin direnci Avrupa ortalamasının, 2014'de \%12'ye yükseldiği görülmektedir. İnvazif $K$. pneumoniae izolatlarında ise üçüncü kuşak sefalosporin direnci Avrupa ortalaması 2011 'de \%24,5'den, 2014'te \%27,4'e yükselmiș, direncin geniş bir yayılım gösterdiği; i̇zlanda'da en düșük (2014 verileri \%3,6), Romanya, Yunanistan ve Slovakya'da en yüksek değerlere (2014 verileri sırasıyla $\% 66,5, \% 67,6$ ve \%70,8) ulaștığı tespit edilmiștir (12).

Çalıșmamızda yıllara göre $E$. coli'lerde GSBL pozitifliği anlamlı bir değișiklik göstermemiștir $(\mathrm{p}=0,21)$. Klebsiella spp.'de ise yillara göre GSBL pozitifliği istatistiksel anlamlı olarak farklıdır $(\mathrm{p}=0,004)$. Bu farkın 2015 yılındaki azalmadan kaynaklandığı görülmektedir. 2015 yılında \%22'ye düșen GSBL oranı ilk bakıșta sevindirici gibi görünse de, beta-laktam antibiyotik direnç oranları tek tek incelendiğinde gözlenen \%50-60'lar seviyesindeki yüksek direnç oranları cihazın okuduğu GSBL oranının gerçeği yansıtmadığını düşündürmektedir. Nitekim cihazın fenotipik direnç açıklamalarında, 22 Klebsiella spp. sușu için "karbapenemaz (+ veya- ESBL)" șeklinde açıklama bulunmaktadır. Bu sușların hepsi tüm betalaktam antibiyotiklere ve ertapeneme dirençlidir ve GSBL test sonucu "negatif" olarak bildirilmektedir. Yapılan 
çalıșmalarda, otomatize sistemlerin karbapenem dirençli K. pneumoniae suşlarındaki GSBL direncini saptamada düșük duyarlılık gösterdiği bildirilmiștir (13, 14). Karatuna ve ark.'nın Vitek 2'nin tümü imipeneme ve/ veya meropeneme dirençli $K$. pneumoniae sușlarındaki karbapenemaz ve GSBL aktivite performansını değerlendirdikleri çalıșmasında; cihazı karbapenemaz uyarı sisteminde bașarılı, GSBL aktivitesini tanımlama konusunda ise yetersiz bulduklarını bildirmişlerdir (15). Otomatize sistem GSBL sonuçları tarama sonuçlarıdır. Yapılan çeșitli çalıșmalarda, Vitek 2 otomatize sistemin $E$. coli ve $K$. pneumoniae için GSBL tespit duyarlılığ \%86-98 aralığında, özgüllüğü de \%78-99 aralığında bildirilmiștir $(16,17)$. Ancak önceki yıllara oranla, çalıșılan suşların direnç profili hariç cihaz ve yöntemde bașka bir değișiklik bulunmamaktadır. Bu nedenle, 2015 yılındaki ani düșüșün otomatize sistemin karbapenem dirençli suşlarda GSBL tespitindeki bașarısızlığına bağlı olduğunu düșündürmüștür.

Hastanemizde yatan hastalardan izole edilen $E$. coli ve Klebsiella spp. sușlarında GSBL olumluluk oranları ülkemizden aynı grup hastalarda tespit edilen oranlarla benzerlik göstermektedir. 01 Ocak 2011 ve 30 Haziran 2015 tarihleri arasında her iki türde de GSBL pozitiflik oranlarının artmamıș olması sevindiricidir. Ancak özellikle karbapenem direnci bulunan sușlarda otomatize sistemin GSBL aktivitesini tanımlamada yetersiz olduğu, bunun yanında ek bir test ile GSBL durumunun araștırılmasının epidemiyolojik açıdan yararlı olacağı düşünülmektedir.

Çalıșmamız verilerine göre her iki bakteriye en etkili antibiyotik kolistindir. $E$. coli için direnç oranları oldukça düșük (\%0-1) bulunsa da, Klebsiella spp.'ler söz konusu olduğunda 2012'deki \%4 direnç, 2015'de \%35'e yükselmiștir. Bradford ve ark. 19.719 adet Enterobactericeae spp. izolatından \%1,6'sında kolistin direnci tespit etmișlerdir (18). Ancak karbapenemaz olumlu 482 suşta bu oran \%12'ye çıkmıștır. Illacın artan kullanımı nedeniyle kaçınılmaz olarakçoklu dirençli Gram negatif bakterilerde kolistine direnç giderek artmaktadır. Yunanistan, Güney Kore veAmerika Birleșik Devletleri gibi birçok ülkedeki hastanelerde mono-multiklonal kolistin dirençli karbapenemaz üreten $K$. pneumoniae’lara bağlı salgınlar tanımlanmıștır (19). Yunanistan'da 2007 yılında yapılan bir çalışmada, çoklu ilaç direnci bulunan patojenlerle enfeksiyon nedeniyle kolistin kullanılan yoğun bakım hastalarında, kolistine dirençli $K$. pneumoniae ile bronșiyal ve bağırsak kolonizasyon oranı \%37 olarak saptanmıștır (20). Karbapenem dirençli K. pneumonia sușlarında da İtalya'da \%43, Türkiye'de \%2,7 kolistin direnci bildirilmiștir $(21,22)$. Yine İtalya'dan bildirilen bir çalıșmada, karbapenemaz üreten $\mathrm{K}$. pneumonia sușlarında kolistin direncinin 2010-2013 yılları arasında \%11'den \%27'ye yükseldiği belirtilmiștir (23). 2015 yılındaki kolistin dirençli 15 sușun üçü orta duyarlı (MIK -Minium İnhibisyon Konsantrasyonu-: $4 \mu \mathrm{g}$ / $\mathrm{mL}$ ) olup, dirençli olarak kabul edilmiștir. Bu sușların 11 'i (\%73) yoğun bakımlardan soyutlanmıștır. İzole edildikleri örneklerin onu (\%67) idrar, dördü (\%27) endotrakeal aspirat, biri (\%6) ise kan kültürüdür. Sușlarnn biri hariç tümü her üç karbapeneme dirençlidir. Çeșitli ülkelerden farklı oranlar bildirilse de Klebsiella spp.'ye artan kolistin direnci, özellikle karbapenem dirençli sușlarda son seçenek antibiyotiklerden biri olduğu göz önünde bulundurulursa endișe verici boyutlarda olduğu görülmektedir.

Çalıșmamız verilerine göre $E$. coli'lere en etkili ikinci antibiyotik grubu olan karbapenemlere düşük direnç oranları (\%1-2) sevindiricidir. UAMDSS'nin 2013 verilerine göre invazif $E$. coli’lerde imipeneme direnç $\% 1,8$, meropeneme \%3,9 direnç oranları tespit edilmiștir (10). Bununla beraber Klebsiella spp.'ler için durum pek parlak görünmemektedir. GSBL olumlu Klebsiella spp. suşlarında karbapenemlerin artan kullanımına bağlı olarak direnç oranları son yıllarda giderek artmıștır. Çalıșmamı sonuçlarına göre karbapenem dirençli Klebsiella spp. (KDK) oranı 2011 yılında \%2-6 iken, 2015 yılında \%50'lere ulașmıștır. Illk karbapenem dirençli $K$. pneumoniae (KDKP) izolatının bildirildiği 2001 yılından bu yana pek çok ülkeden (İsrail, Çin, Yunanistan, Porto Riko, Kolombiya, Fransa, İspanya, Almanya ve Suudi Arabistan gibi) KDKP salgınları bildirilmiștir (24). 2014 yılında Avrupa'da invazif KDKP oranı ortalama \%7,3 olmakla beraber ülkeler arasında büyük oran farklılıkları bulunmaktadır. Örneğin Estonya, Finlandiya, İzlanda gibi kuzey ülkelerinde direnç bildirilmezken, Romanya, İtalya ve Yunanistan gibi güney ülkelerinde çok yüksek direnç oranları (sırasıyla \%31,5, \%32,9 ve \%62,3) belirtilmektedir (12). 
UAMDSS'nin 2013 verilerine göre ülkemizde invazif Klebsiella izolatlarına ortalama direnç imipenem için \%16, meropenem için ise \%15,4 görülmektedir (10). Çalışmamızın aynı yıl verilerine bakıldığında; hastanemizin yatan hastalarında KDK oranlarının (\%0-6) ülke ortalamalarının oldukça altında bulunduğu, ancak 2014 ve 2015 yıllarında ise hastanemiz KDK oranının hızla arttığı (\%38-52) görülmektedir. KDK gelișimi ile daha önce karbapenem ve üçüncü kușak sefalosporin tedavisi alınması arasında anlamlı ilișki olduğu bildirilmiștir (25). Karbapenemlere duyarlı suşların tedavisinde karbapenemlerin monoterapi olarak kullanılmaması ve KDK sușları tespit edildiğinde acil enfeksiyon kontrol önlemlerinin alınması gerekliliği görülmektedir.

Amikasin E. coli’lere en etkili üçüncü, Klebsiella spp.'lere ise ikinci antibiyotiktir. Hastanemizde, amikasin direnci yıllar içinde $E$. coli'lerde (ortalama \%12) azalmış $(\mathrm{p}=0,000)$, Klebsiella spp.'ler (ortalama \%22) ise tersine artmıştır $(\mathrm{p}=0,000)$. Diğer taraftan diğer bir aminoglikozit olan gentamisine her iki türde de, amikasine göre daha yüksek direnç oranları gözlenmektedir.

Kinolonlara karșı direncin ise $E$. coli (ortalama \%5055) ve Klebsiella spp. (ortalama \%46-49) için oldukça yüksek oranlara ulaştığı gözlenmektedir. Aynı șekilde trimetoprim-sulfametoksazol direnci de her iki tür bakteri için yüksektir.

Piperasilin-tazobaktam, sefepim ve sefoksitin düșük direnç oranları (sırayla ortalama \%16, \%16 ve \%19) ile $E$. coli tedavisinde, hastanemiz yatan hastalarında kullanılabilecek alternatif ilaçlardan olduğu görülmektedir. Ancak değerlendirmeye alınan diğer antibiyotiklerden ampisilin, amoksisilin-klavulonik asit ve diğer sefalosporinlere yüksek direnç oranları bulunmaktadır. Klebsiella spp.'lerin ise beta-laktamaz inhibitörü kombine bileșikler ve tüm sefalosporinlere 2015 yilında yüksek direnç oranları gösterdiği tespit edilmiştir.

Çalıșmamızın kısıtlılıkları; geriye dönük otomatize sistem verilerinin değerlendirildiği bir çalıșma olması nedeniyle karbapenem dirençli, GSBL olumsuz suşlarda GSBL doğrulama testleri yapılamamıștır. Bunun yanında devlet hastanesi șartlarında fiziksel ve finansal kısıtlılıklar nedeniyle sușların moleküler düzeyde beta-laktamaz ve karbapenemaz tiplerinin tayini ve salgın araștırması için suşlar arası genetik yakınlık tespitinin yapılamamış olması çalıșmamızın kısıtlılıkları arasında yer almıştır.

Sonuç olarak; hastanemizde yatan hastalardan izole edilen $E$. coli ve Klebsiella spp. türleri için antibiyotik direnci önemli bir sorundur. Çeșitli antibiyotik kombinasyonları ile tedavi edilmeye çalıșllan bu suşlarla oluşan enfeksiyonlar endișe vericidir ve acil müdahale gerektirmektedir. Hastane içi yayılımın engellenmesi için sușların kısa zamanda tespiti, bu sușları tașıyan hastaların tek kişilik odalara alınması, katı temas izolasyonu, el hijyeni ve diğer enfeksiyon kontrol önlemlerine yönelik eğitimlerin tekrarlanarak uyumun arttırılması, ampirik tedavide antibiyotiklerin kombine şekilde kullanılmalarının tercih edilmesi gerekmektedir.

\section{KAYNAKLAR}

1. Al-Muhtaseb M, Kaygusuz A. Kan kültürlerinden izole edilen Escherichia coli ve Klebsiella pneumoniae sușlarında genișlemiș spektrumlu beta-laktamaz (GSBL) sıklığı. ANKEM Derg, 2008; 22 (4): 175-82.

2. Akyar I, Kocagöz S, Kocagöz T, Sarıgüzel Sar N, Gültekin $M$, Ercis $S$ ve ark. Beș yılda izole edilen 15434 Escherichia coli ve 3178 Klebsiella spp. suşunda genișlemiş spektrumlu beta-laktamaz üretiminin ylllara, kliniklere ve örnek türlerine dağılımı. ANKEM, 2010; 24 (1): 34-41.

3. Ağca H. Escherichia coli ve Klebsiella pneumoniae suşlarının genișlemiș spektrumlu beta-laktamaz üretimleri ve antibiyotik duyarlılık oranları. DEÜ Tıp Fak Derg, 2011; 25 (3): 169-73.
4. Mehli M, Zer Y, Gayyurhan E. Ceșitli klinik örneklerden izole edilen Enterobactericeae suşlarında GSBL olușturmanın ÇDST ve Vitek 2 yöntemleri ile araștırılması. ANKEM, 2007; 21 (2): 71-5.

5. Baykal A, Çöplü N, Şimșek H, Esen B, Gür D. Kan izolatı $E$. coli ve $K$. pneumoniae sușlarında genișlemiș spektrumlu beta-laktamaz, KPC tip karbapenemaz ve plazmid aracılı AmpC betalaktamaz varlığının araștırılması. Mikrobiyol Bul, 2012; 46 (2): 159-69.

6. Ișıkgöz Taşbakan M, Pullukçu H, Sipahi OR, Yamazhan T, Arda B, Ulusoy S. A pooled analyses of the resistance patterns of Escherichia coli strains isolated from urine cultures from Turkey: a comparision of the periods 19972001 and 2002-2007. Turk J Med Sci, 2011; 41 (3): 557-64. 
7. Ișık F, Arslan U, Tuncer I. Kan kültürlerinden izole edilen Klebsiella pneumoniae sușlarında genișlemiș spektrumlu beta-laktamaz varlığı ve antibiyotik duyarlılıkları. Mikrobiyol Bul, 2008; 42: 131-6.

8. Uyanık MH, Hancı H, Yazgı H, Karameșe M. Kan kültürlerinden soyutlanan Escherichia coli ve Klebsiella pneumoniae sușlarında GSBL sıklığı ve ertapenem dahil çeșitli antibiyotiklere in-vitro duyarlılıkları. Ankem, 2010; 24 (2): 86-91.

9. Karahocagil MH, Yaman G, Göktaș U, Sünnetçioğlu M, Çıkman A, Bilici A ve ark. Hastane enfeksiyon etkenlerinin ve direnç profillerinin belirlenmesi. Van Tip Derg, 2011; 18 (1): 27-32.

10. Anonymous. Ulusal Antimikrobiyal Direnç Surveyans Sistemi, 2013 Yılı Yıllık Raporu, Türkiye Halk Sağlığı Kurumu, Sağlık Bakanlığı, Ankara. http://uamdss. thsk.gov.tr Erişim tarihi: 20.01.2016.

11. Sader HS, Farrell DJ, Flamm RK, Jones RN. Antimicrobial susceptibility of Gram-negative organisms isolated from patients hospitalised with pneumoniae in US and European hospitals: results from the SENTRY Antimicrobial Surveillance Program, 2009-2012. Int J Antimicrob Agents, 2014; 43 (4): 328-34.

12. Anonymous. Antimicrobial resistance surveillance in Europe. Annual report of the European antimicrobial resistance surveillance network (EARS-Net) 2014. Stockholm: ECDC; 2015. Erișim Tarihi: 05.12.2015. Available from: www.ecdc. europa.eu.

13. Endimiani A, Perez F, Bajaksouzian S, Windau AR, Good CE, Choudhary Y et al. Evaluation of updated interpretative criteria for categorising Klebsiella pneumoniae with reduced carbapenem susceptibility. J Clin Microbiol, 2010; 48 (12): 4417-25.

14. Dağlar D, Öngün G. Genișlemiș spektrumlu betalaktamazlar (GSBL) ve tanı yöntemleri. İnönü Üni Sağ Bil Derg, 2012; 1: 1-19.

15. Karatuna O, Altınkanat G, Söyletir G. Performance of Vitek 2 for the detection of carbapenemase and extended-spectrum B-lactamase activity in selected Klebsiella pneumoniae isolates and evaluation of different methods (Abstract). 20th ECCMID. April, 10-13, Vienna-Austria. 2010.

16. Spanu T, Sanguinetti $M$, Tumbarello $M$, D'Inzeo T, Fiori B, Posteraro B et al. Evaluation of the new Vitek 2 extended-spectrum beta-lactamase (ESBL) for rapid detection of ESBL production in Enterobactericeae isolates. J Clin Microbiol, 2006; 44 (9): 3257-62.

17. Wiegand I, Heinrich KG, Dietrich M, Stürenburg E, Seifert $H$. Detection of extended-spectrum betalactamases among Enterobactericeae by use of semiautomated microbiology systems and manual detection procedures. J Clin Microbiol, 2007; 45 (4): 1167-74.
18. Bradford PA, Kazmierczak KM, Biedenbach DJ, Wise MG, Hackel M, Sahm DF. Colistin-resistant Enterobactericeae: correlation of beta-lactamase production and colistin resistance among isolates from a global surveillance program. Antimicrobiob Agents Chemother, Doi: 10.1128/AAC.01870-15; Accepted manuscript posted online 14 December 2015.

19. Mammina C, Bonura C, Bernardo F Di, Aleo A, Fasciana T, Sodano $C$ et al. Ongoing spread of colistin-resistant Klebsiella pneumoniae in different wards of an acute general hospital, Italy, June to December 2011. Euro Surveill. 2012; 17(33): pii=20248. Erișim tarihi: 05.01.2016. Available online: http://www.eurosurveillance.org/ ViewArticle. aspx?Articleld=20248.

20. Antoniadou A, Kontopidou F, Poulakou P, Koratzanis $\mathrm{E}$, Galani E, Papadomichelakis E. colistin-resistant isolates of Klebsiella pneumoniae in intensive care unit patients: first report of a multiclonal cluster. J Antimicrob Chemother, 2007; 59: 786-90.

21. Monaco M, Giani T, Raffone M, Arena F, GarciaFernandez A, Pollini $S$ et al. Colistin resistance superimposed to endemic carbapenem-resistant Klebsiella pneumoniae: a rapidly evolving problem in Italy, November2013 to April 2014. Euro Surveill, 2014; 19 (42): pii=20939. Erișim tarihi: 05.01.2016. Available online: http://www.eurosurveillance. org/ViewArticle. aspx?Articleld=20939.

22. Iraz $M$, Düzgün AÖ, Sandallı $C$, Doymaz $M Z$, Akkoyunlu Y, Saral A et al. Distribution of B-lactamase genes among carbapenem-resistant Klebsiella pneumoniae strains isolated from patients in Turkey. Ann Lab Med, 2015; 35: 595601.

23. Tumbarello $M$, Viale $P$, Bassetti $M$, De Rosa FG, Spanu T, Viscoli C. Infections caused by KPCproducing Klebsiella pneumoniae: differences in therapy and mortality in a multicentre studyauthor's response. J Antimicrob Chemother, doi: $10.1093 / \mathrm{jac} / \mathrm{dkv} 200$ First published online: 13 July 2015.

24. Saidel-Odes L, Borer A. Limiting and controlling carbapenem-resistant Klebsiella pneumoniae. Infectand Drug Resist, 2014; 7: 9-14.

25. Candevir Ulu A, Kurtaran B, İnal AS, Kömür S, Kibar F, Yapıcı Çiçekdemir H et al. Risk factors of carbapenem-resistant Klebsiella pneumoniae infection: a serious threat in ICUs. Med Sci Monit, 2015; 21: 219-24. 